\title{
Adverse effects of medicinal herbs on the human kidney
}

\author{
Efeitos adversos de ervas medicinais no rim humano
}

\author{
Matheus Santana Figueredo모 Fernanda Moraes Schroeder ${ }^{1}$, \\ Rodrigo Vieira Soares ${ }^{1}$, Claudia Maria de Barros Helou ${ }^{2}$
}

Figueredo MS, Schroeder FM, Soares RV, Helou CMB. Adverse effects of medicinal herbs on the human kidney / Efeitos adversos de ervas medicinais no rim humano. Rev Med (São Paulo). 2018 jan.-fev.;97(1):51-8.

RESUMO: Mais da metade da população mundial utiliza ervas medicinais (EM) no cuidado da sua saúde devido a tradições ou a crenças falsas relacionadas a produtos naturais. Entretanto, as EM contêm princípios ativos que podem causar efeitos adversos nos rins, muitos dos quais subestimados. Esse manuscristo, parte de uma disciplina do curso de graduação de medicina, objetiva estudar os efeitos adversos de EM nos rins humanos. Assim, com o uso dos unitermos medicinal herbs, kidney e adverse effects nas bases de dados PubMed, LILACS e Scopus, 11 trabalhos científicos foram selecionados com o objetivo de se delinear um melhor entendimento sobre o assunto. A maior parte das publicações eram relatos de caso, enquanto apenas uma se tratava de um ensaio de maior rigor, no caso um estudo randomizado controlado, ressoando com dados da literatura. Além disso, nenhum estudo que refletisse mais a realidade brasileira em relação ao tema foi encontrado. Assim, políticas públicas em saúde devem ser direcionadas para orientar os profissionais da saúde sobre a relevância do assunto, capacitando-os a orientar a população sobre o uso das EM de maneira mais segura e eficiente.

Descritores: Rim; Plantas medicinais/efeitos adversos; Medicina tradicional/efeitos adversos; Lesão renal aguda; Inibidores de calcineurina/efeitos de drogas; Fitoterapia/efeitos adversos.

\begin{abstract}
More than half of world's population rely on medicinal herbs $(\mathrm{MH})$ as a source of self care, which is often associated with traditions or misconceptions regarding natural products. However, MH contain many active principles that can induce adverse effects on the kidney, most of which underestimated. This manuscript, part of a Medicine graduate school subject, aims to study the adverse effects of $\mathrm{MH}$ on the human kidneys. Using the keywords "medicinal herbs", "kidney" and "adverse effects" on PubMed, LILACS and Scopus, 11 scientific publications were selected in order to provide a better understanding of this matter. Most of these publications consisted of case-report, whereas only one consisted of a more scientifically strict study, a randomized controlled trial in this case, corroborating with the scientific literature regarding it. There was also no scientific paper that reflected more the subject's reality in Brazil. Hence, health public policies should be directed to provide health professionals with scientific knowledge about the subject's relevance, thus allowing them to guide the population on how to take $\mathrm{MH}$ in a safer and more efficient way.
\end{abstract}

Keywords: Kidney; Plants, medicinal/adverse effects; Medicine, traditional/adverse effects; Acute kidney injury; Calcineurin inhibitors/drugs effects; Phytotherapy/adverse effects.

Artigo desenvolvido na Disciplina Optativa “Abordagem Prática da Escrita Científica” sob coordenação da Revista de Medicina do DC-FMUSP.

1. Faculdade de Medicina FMUSP, Universidade de Sao Paulo, Sao Paulo, SP, BR. Undergraduate students of FMUSP. Email: matheus.figueredo@fm.usp.br, http://orcid.org/0000-0002-7524-1728; schroeder@fm.usp.br, http://orcid.org/0000-0001-6566-9387; vieirasoares@gmail.com, http://orcid.org/0000-0002-1682-9783.

2. Laboratório de Pesquisa Básica (LIM 12), Nefrologia, Hospital das Clínicas HCFMUSP, Faculdade de Medicina FMUSP, Universidade de Sao Paulo, Sao Paulo, SP, BR. Email: chelou@usp.br; http://orcid.org/0000-0002-2228-6041.

Corresponding author: Matheus Santana Figueredo. Av. Doutor Arnaldo 455, sala 3310. 01246-903 São Paulo, SP, BR. Email:

matheus.figueredo@fm.usp.br. 


\section{INTRODUCTION}

$\mathrm{T}^{\mathrm{s}}$ he usage of medicinal herbs $(\mathrm{MH})$ is a topic of great relevance both for social aspects and for clinical practice. In 2005, around four billion people living in developing countries regarded $\mathrm{MH}$ as a primary source of care, representing $80 \%$ of world population then ${ }^{1}$. Similarly, the developed world has been reporting an increasing raise of this usage, as testified by the consumption of herbal products amidst one fifth of American adults as of $2002^{2}$. Among the reasons for the high consumption of $\mathrm{MH}$ nowadays are: traditional beliefs associated with cultural identity, mostly in developing countries, and the concept that herbs are non-processed products of nature, therefore safe and beneficial ${ }^{3,4}$.

We surely cannot deny the importance of plants in medical practice because around $60 \%$ of present-day therapeutic arsenal has its active principle derived from plants and plenty of herbs are in fact salutary ${ }^{3}$. However, the pharmacokinetic and pharmacodynamics of chemicals present in $\mathrm{MH}$ are not well known, much less their interaction with the human kidneys ${ }^{4}$. Furthermore, only few of these herbs has been tested in randomized controlled trials, for reasons which include lack of standardization ${ }^{4,5}$. On the other hand, one can find many clinical cases in scientific literature reporting the usage of $\mathrm{MH}$ associated with electrolyte disorders, renal diseases or unwanted drug interactions with these herbs in the kidneys. Diseases reported in these studies include acute tubular necrosis, acute interstitial nephritis, acquired Fanconi's syndrome, pseudohyperaldosteronism, hyperkalemia, papillary necrosis, chronic interstitial fibrosis, nephrolithiasis, and even urinary tract cancer ${ }^{6-14}$.

Another point to be emphasized regarding herbal poisoning is that preparations are rarely standardized, in contrast to pharmaceutical products ${ }^{15}$. In fact, plants themselves are a complex system of substances, some of them beneficial and others potentially harmful ${ }^{3,4,15}$. Reasons why preparations may be non-homogeneous include misidentification of species, different growth conditions, diversified techniques to process extracts, frequent contamination by other substances (including conventional medication, allergens and heavy metals), and lack of information about pharmacologically active chemicals, as previously discussed ${ }^{3,15}$.

Bargnis et al. ${ }^{16}$ proposed a four-category classification that elucidates how MH caused renal poisoning in their review of case reports. These are: (a) herbs properly identified, with unknown or underestimated toxicity; (b) herbs contaminated with drugs, hormones, or heavy metals; (c) herbs incorrectly identified; and (d) herb interactions with conventional drugs for taking these medications mostly consist of recurrent afflictions, such as erectile dysfunction, constipation and menstrual disorders, even though they can cause fatal adverse effects ${ }^{17-20}$.
In the first category, (a), we for instance have licorice (Glycyrrhiza glabra), an herb that contains glycyrrhizin and glycyrrhetinic acids. Both of these have an aldosterone-like effect $^{21}$. Consequently, prolonged licorice consumption can cause sodium and water retention, hypokalemia, metabolic alkalosis, hypertension, suppression of the reninaldosterone axis, among other adverse effects ${ }^{9,21,22}$.

The second category, (b), may be illustrated by a clinical case wherein a patient who had been treating his arthralgia with Tung Shueh pills developed acute renal failure after four weeks of treatment ${ }^{23}$. Further laboratory investigation revealed that diazepam and mefanamic acid were also found in the herbal preparation ${ }^{23}$. In the third category, (c), we find herbal preparations containing a misleading identification. An example of such is an incident that took place in Belgium, in which nine women suddenly presented with extensive interstitial fibrosis of the kidney that rapidly progressed to renal failure ${ }^{24}$. The only link among these women was weight loss pills, which claimed to contain only two well-known Chinese MH, Stephania tetrandra and Magnolia officinalis. Nevertheless, further analysis revealed that the drugs had been contaminated with Aristolochia spp., a dangerous nephrotoxic herb ${ }^{24}$. Finally, the fourth category, (d), includes unwanted interactions between herbal plants and conventional drugs, usually modifying the bioavailability of the latter. In this case, we can cite interactions of St John's wort and renal transplant drugs, such as the lowering of cyclosporine serum levels induced by this herb ${ }^{25}$.

There are several definitions of $\mathrm{MH}$, one of which describes these medicines as products that contain as an active ingredient parts of plants, whose consumption is culturally established and widely believed to be beneficial to one's health, whether promoting general well-being, preventing diseases or actually curing them ${ }^{26}$. This is the definition we are going to hold throughout our essay. Moreover, in agreement with the goals of the study hereinafter presented, we have decided to consider only non-industrialized $\mathrm{MH}$ whose intake is done orally, such as teas, decoctions and other infusion products. Considering the obvious social importance of the subject and the lack of information currently available, as well as the kidneys' role in the clearance of substances and regulation of water and electrolytes homeostasis, we aim to verify in the literature the possible adverse effects of $\mathrm{MH}$ on renal function in humans. This publication is part of a graduation subject about scientific writing in the Faculdade de Medicina da Universidade de São Paulo.

\section{METHODS AND MATERIALS}

We conducted an electronic literature research in April 2017 to collect papers which analyzed the correlation between the use of medicinal plants and their adverse effects on the kidney. We used the keywords "medicinal 
herbs", "kidney" and "adverse effects" on the following electronic databases: PubMed, SCOPUS, SciELO and LILACS. Publications that lacked an abstract, approached only effects of industrialized products and were neither in Portuguese nor in English were ruled out, as well as studies on animals or in vitro.

Besides, our search was amplified by means of one systematic review ${ }^{27}$ and two reviews ${ }^{16,28}$ about this theme, both of which found throughout our electronic investigation. We have aditionally hand-picked another reference considering its value to our discussion (using only the keywords "medicinal herbs" and kidney"), although it could not be found through the aforementioned keyword search. Other than that, all of those publications naturally met our criteria.

\section{RESULTS}

As illustrated in Figure 1, we only found five publications which matched our inclusion criteria in our electronic search initially, and all of them were case reports $^{29-33}$. Furthermore, we have gathered other five publications through the reviews ${ }^{34-38}$ and another case report ${ }^{39}$ has been manually selected. Therefore, our research resulted in 11 different publications.

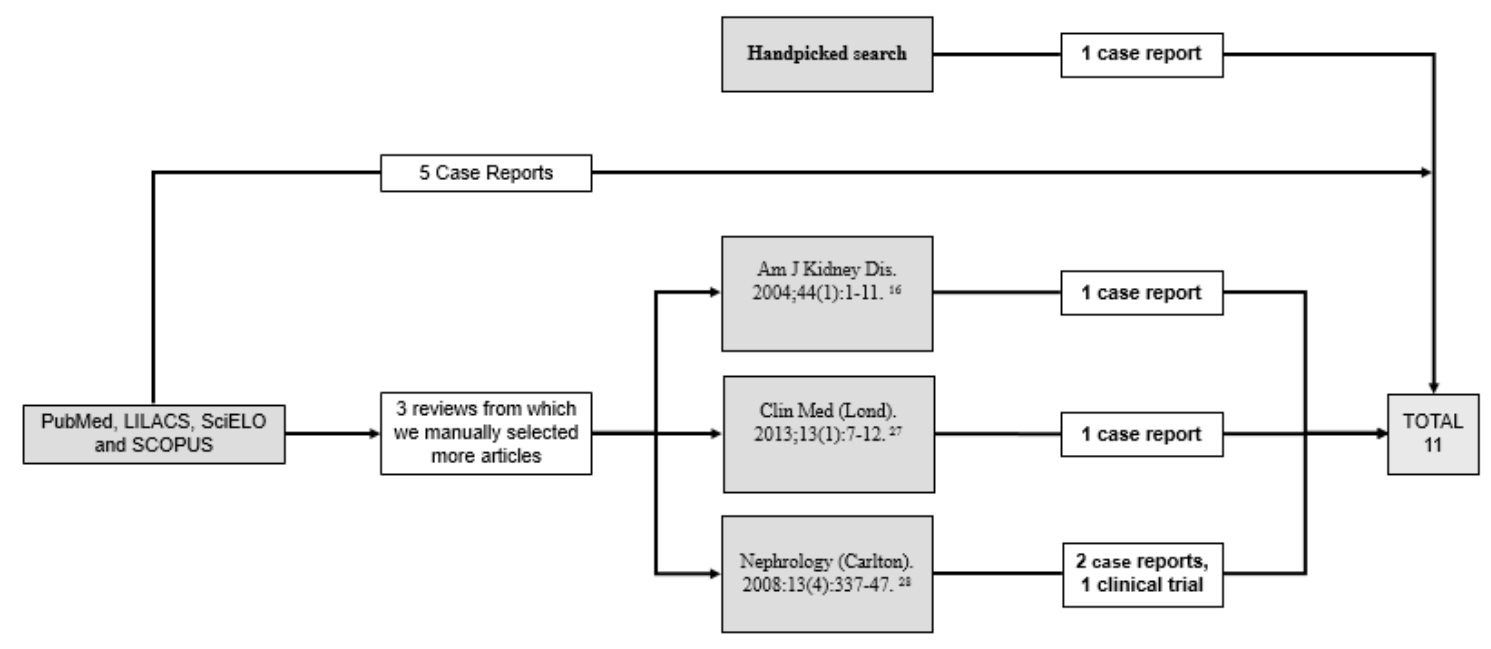

Figure 1. Results found through electronic and manual searches

Ten out of eleven publications were case-reports, as shown in Table 1, the other one being a clinical trial ${ }^{38}$. These ten publications were grouped into four categories depending on how the kidney was affected: i. acute renal failure in patients without confirmed previous renal disease; ii. toxic raise of calcineurin inhibitor levels in transplanted renal patients; iii. hydroelectrolytic disorder with previous renal disease; iv. acute renal failure in patients with confirmed previous renal disease.

Table 1. Medicinal herbs and their respective effect on the kidneys: outcomes from the case- reports

\begin{tabular}{|c|c|}
\hline Medicinal herb & Adverse effects in human kidney \\
\hline Yam (Dioscorea quinqueloba $)^{30}$ & \multirow{5}{*}{ i. Acute renal failure in patient without confirmed previous renal disease } \\
\hline Henna (Lawsonia inermis) $)^{31}$ & \\
\hline Jering bean (Pithecellobium jeringa $)^{32}$ & \\
\hline Lei Gong Teng (Tripterygium wilfordii) ${ }^{37}$ & \\
\hline Tribulus terrestris water ${ }^{39}$ & \\
\hline Chamomile tea (Matricaria chamomilla) $)^{33,36}$ & \multirow{2}{*}{ ii. Toxic raise of calcineurin inhibitor levels in transplanted renal patients } \\
\hline Pomelo (Citrus maxima) $)^{35}$ & \\
\hline Noni juice (Morinda citrifolia) ${ }^{34}$ & iii. Hydroelectrolytic disorder in a chronic kidney disease patient \\
\hline Sea spurge (Euphorbia paralias) ${ }^{29}$ & iv. Acute renal failure in patients with a history of renal disease \\
\hline
\end{tabular}

As illustrated in Figure 2, most of case reports fall into category i. 


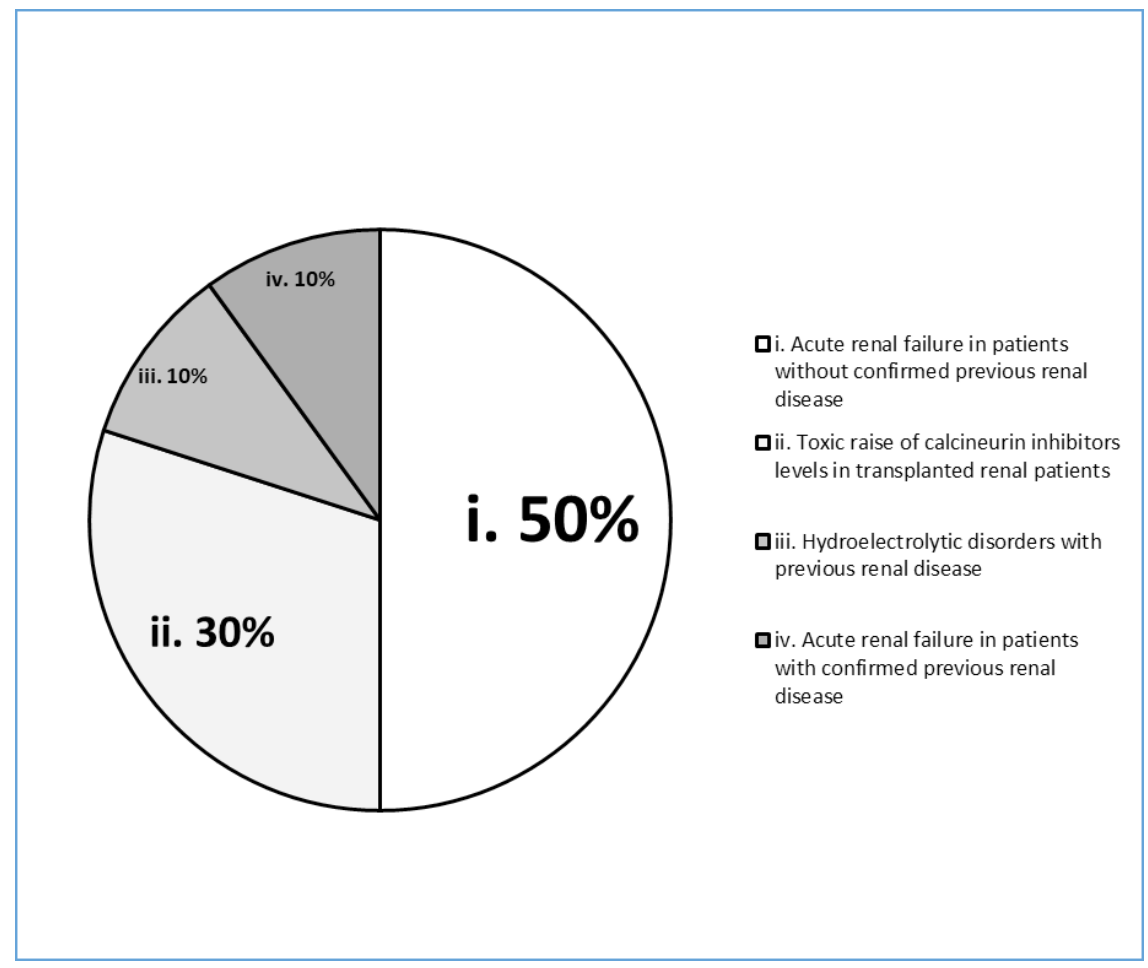

Figure 2. Number of case reports per category, based upon the type of adverse renal effect

\section{DISCUSSION}

Our results showed how little MH are appreciated by more rigorous scientific assays, such as randomized controlled trials, leaving space to testimonial studies (i.e., case reports), as already stablished by the literature ${ }^{5}$. Case reports are very limited due to their very nature, as subjects of study are selected upon unusual attributes. We will firstly discuss the adverse renal effects exerted by $\mathrm{MH}$ described in these case reports individually, followed by the discussion of other types of publications.

Sea spurge (Euphorbia paralias), yam (Dioscorea quinqueloba), jering bean (Pithecellobium jeringa) and noni (Morinda citrifolia) cases of poisoning belong to the underestimated toxicity category. Sea spurge is an herb usually taken on grounds of its alleged anti-inflammatory, purgative and anesthetic properties. In Tunisia, a 29-yearold male patient, who had been on a 13-year follow-up for a discreet proteinuria caused by nephrotic syndrome, took boiled sea spurge for an edema treatment over a 10-day period. Later, he was admitted at hospital presenting with acute renal failure, with a serum creatinine of $2.71 \mathrm{mg} / \mathrm{dL}$, and an intense worsening of his proteinuria. According to a kidney biopsy, tubular necrosis was the mechanism behind Euphorbia paralias poisoning ${ }^{29}$.

Yam is often used as a food supplement. Popular beliefs claim its therapeutic effects against atherosclerosis, acute myocardial infarction and asthma. Boiling, steaming and baking are usually thought to be secure ways of ingesting yams. However, a publication described a clinical case of a male patient with no history of kidney disease in South Korea, who had ingested crude yam juice. He presented with acute renal failure, with creatinine serum levels raising to $8.6 \mathrm{mg} / \mathrm{dL}$, seizures and toxic encephalopathy, despite absence of previous renal disease. Hemodialysis was then necessary ${ }^{30}$.

Jering bean is an important cause of renal damage and acute renal failure, mainly in the tropical regions, where it is consumed daily as a component of local diet. However, it is associated with formation of needle-shaped uric acid crystals in the distal convoluted tubules, causing a severe acute anuric renal failure. This was the case of a previously healthy 45 - year- old patient that presented with colic pain in the left loin, hematuria and oliguria over three days. At hospital admission, he was utterly anuric. The serum creatinine levels raised from $1.33 \mathrm{mg} / \mathrm{dL}$ to 9.5 $\mathrm{mg} / \mathrm{dL}$ in a period of four days, when a bilateral ureteric stenting showed to be decisive in his treatment. Further clinical investigation revealed that the patient had been taking jering bean, which had been previously implicated in renal diseases ${ }^{32}$.

Some $\mathrm{MH}$, in turn, may represent a hazard especially to those who have a history of kidney disease. For instance, Kathleen A. Prag et al. ${ }^{34}$ reported a case of a patient with chronic renal disease (serum creatinine and urea of 4.0 and $50 \mathrm{mg} / \mathrm{dL}$, respectively) that sustained daily consumption of Noni juice on grounds of its purportedly antineoplastic properties. The patient developed a persistent hypercalemia due to a high potassium content $(51 \mathrm{mEq} / \mathrm{L})$ in the juice.

Tribulus terrestris poisoning also belongs to 
the category of herbs with unknown or underestimated toxicity. Its use has been popularized only recently as a way to enhance athletic performance and minimize sexual problems ${ }^{40}$, such as infertility. Moreover, its traditional usage is associated with allegedly therapeutic properties, for example its aphrodisiac and antiurolithiatic activities $^{41,42}$. Recently, a case of severe nephrotoxicity secondary to consumption of Tribulus terrestris water, taken prophylactically against urolithiasis, was described in a 28-year-old healthy man from Iran with a history of urolithiasis $^{39}$. He was admitted two days after starting the herbal treatment, presenting with seizures, severe weakness in lower limbs, malaise, poor appetite and rising blood pressure (180/110 $\mathrm{mmHg}$ at admission). The patient progressed presenting with hepatotoxicity (aminotransferases up to more than 40 times the upper limits of normal range), neurotoxicity and nephrotoxicity. His blood tests and urine analysis showed important impaired renal function with serum creatinine of $17.4 \mathrm{mg} /$ $\mathrm{dL}$, urea concentration of $141 \mathrm{mg} / \mathrm{dL}$, proteinuria of 0.28 $\mathrm{g}$ /day and hematuria. Due to the seriousness of his clinical status, hemodialysis was started ${ }^{39}$.

On the other hand, there are plants whose likely toxicity is known (mainly from animal studies), but whose adverse effects on humans are still not well described. For instance, Tripterygium wilfordii Hook F. (TWHF), also known as thunder god vine, is a Chinese MH traditionally used for over 2000 years as a treatment for arthritis and inflammatory tissue swelling. Recently, researches have been trying to investigate if its active principle could be used as immunosuppressant in the treatment of systemic lupus erythematosus ${ }^{43,44}$. Despite this, therapies using the TWHF are known to be associated with gastrointestinal disorders, infertility and suppression of lymphocyte proliferation. However, little is known about its potential lethal complications. A 36-year-old healthy man was admitted at a hospital owing to severe diarrhea, vomiting and hypotension 10 hours after taking TWHF water. Clinical manifestation of toxicity included cold extremities, mild cyanosis, leukopenia, thrombocytopenia, mild elevation of hepatic and cardiac enzymes, azotemia (urea nitrogen of 32 $\mathrm{mg} / \mathrm{dL}$ and serum creatinine of $2.7 \mathrm{mg} / \mathrm{dL}$ ), hypocalcemia (total calcium of $1.83 \mathrm{mmol} / \mathrm{L}$ ), anuria and metabolic acidosis ( $\mathrm{pH}$ 7.33). As a result, the patient presented with deterioration of renal function, caused not only by herbal nephrotoxicity but also by prolonged hypovolemic shock, and ultimately evolved to death ${ }^{37}$.

As previously stated, MH preparations may be contaminated with toxic substances, such as paraphenylenediamine (PPD). This substance is usually mixed with plants (including henna, after which the dye is named) to form a dye that is traditionally applied to the skin in Northern Africa, Middle East and India. PPD ingestion with $\mathrm{MH}$ is thus frequently reported in those regions, producing from severe edema (also comprising the upper airway tract) to hemolysis, rhabdomyolysis and acute tubular necrosis ${ }^{45}$. Qurashi et al. ${ }^{31}$ exemplified a PPD poisoning reporting henna usage with a 32-year-old patient, who ingested large portions of boiled henna as a treatment to irritable bowel syndrome. He was later brought to a hospital showing signs of intense hemolysis, confirmed by laboratorial investigation. Subsequently, he developed acute renal failure (serum creatinine from $1.56 \mathrm{mg} / \mathrm{dL}$ on day 1 to $7.50 \mathrm{mg} / \mathrm{dL}$ on day 5; serum urea from $41.73 \mathrm{mg} /$ $\mathrm{dL}$ on day 1 to $82.05 \mathrm{mg} / \mathrm{dL}$ on day 5) and had to undergo hemodialysis for a 17-day-period.

Since usage of $\mathrm{MH}$ has been trivialized and disseminated, some patients in special conditions, such as immunosuppression, might not realize that the consumption of these products could worsen their medical condition. Hypericum perforatum L., also known as St John's wort, is commonly used in the treatment of mild to moderate depressive disorders and may pose as an illustration. Interestingly enough, some clinical trials have shown that extracts of St John's wort may be more effective than placebo and equally as effective as conventional antidepressants, even though further assays are necessary ${ }^{46-48}$.

Nevertheless, research has been revealing the capability of St. John's wort to interact with other drugs, especially those metabolized by the CYP3A4 enzyme, a member of the cytochrome P-450 system family ${ }^{49}$. Some of these drugs are calcineurin inhibitors (CNI), which include cyclosporine, an immunosuppressant drug approved by the FDA to treat and prevent allograft rejection in different types of organ transplant, including kidney transplant. Ingestion of St John's Wort may decrease the bioavailability of CNI out of the therapeutic range, causing acute rejection in renal transplant patients, as attested by case reports ${ }^{50,51}$.

On the other hand, grapefruit, Seville orange, pomelo and chamomile can modulate the activity of CYP3A causing increases in patients' CNI serum levels ${ }^{49,52,53}$. There are two case reports on the adverse effects of chamomile tea, both of them due to ingestion of a large amount of chamomile tea by transplanted patients treated with $\mathrm{CNI}^{33,36}$. In these cases, there was a sudden increase of serum CNI levels that came back to therapeutical range after discontinuation of consumption. There is also a case report on pomelo intake that also had a similar outcome, wherein a patient took $100 \mathrm{~g}$ of the fruit ${ }^{35}$.

A study on renal transplant patients conducted by Lown et al showed that P-glycoprotein ( $p-G p)$, which is an ATP-binding cassette $(\mathrm{ABC})$ transporter also involved in the hepatic metabolism of xenobiotics, is more important to cyclosporine bioavailability than that exerted by intestinal CYP3A4 activity ${ }^{54}$. Furthermore, clinical trials have reported that some herbs can selectively interfere with this process, such as grapefruit ${ }^{38}$.

One of these clinical trials was a randomized crossover study consisting of seven healthy volunteers 
Figueredo MS, et al. Adverse effects of medicinal herbs on the human kidney.

(5 men and 2 women). They were offered grapefruit juice, Seville orange juice or water with the same oral dose of cyclosporine $(7.5 \mathrm{mg} / \mathrm{mL})$, whose bioavailability was measured over time. Grapefruit juice was revealed to significantly increase cyclosporine bioavailability compared to Seville orange juice and water, which had no statistical difference whatsoever ${ }^{38}$.

As both grapefruit and Seville orange juice inhibit the CYP3A4 activity, but only grapefruit causes P-glycoprotein activity to decrease, these results suggest that the most important effect on cyclosporine concentration is mediated by $\mathrm{P}$-glycoprotein regulation, as previously shown by Lown et $\mathrm{al}^{38,54}$. Moreover, they offer a more solid ground on how grapefruit juice consumption can be harmful to renal transplant patients, as higher blood levels of cyclosporine may cause hyperuricemia secondary to a decrease in glomerular filtration rate and chronic tubulopathy ${ }^{55,56}$.

\section{CONCLUSION}

Availability of scientific material concerning herbal-related adverse effects on the human kidney is still scanty. As a consequence, most of publications consist of case reports, studies which are inexpensive and quick to conduct. These testimonial studies have, however, a series of limitations due to their very nature, such as the inability to establish a strong cause-effect relationship and the impossibility to test hypotheses on treatment efficacy. Also, case reports are highly prone to selection bias insofar as patients are picked depending on their outcome. Therefore, case reports may not be such a trustworthy source of scientific material, although they potentially represent a starting point for further research.

Since the usage of $\mathrm{MH}$, especially in the developing world, finds its strength in empiricism, popular culture and

\section{REFERENCES}

1. Bodeker G. WHO global atlas on traditional, complementary and alternative medicine (TCAM). Iranian J Pharm Res. 2010;3(Suppl 2):25. Available from: http://ijpr.sbmu.ac.ir/ article_366.html.

2. Barnes PM, Powell-Griner E, McFann K, Nahin RL. Complementary and alternative medicine use among adults: United States, 2002. Adv Data. 2004(343):1-19. doi: 10.1016/j.sigm.2004.07.003.

3. Ardalan M-R, Rafieian-Kopaei M. Is the safety of herbal medicines for kidneys under question? J Nephropharmacol. 2013;2(2):11-2. Available from: https://www.ncbi.nlm.nih. gov/pmc/articles/PMC5297543/.

4. Smet PA. Herbal remedies. N Engl J Med. 2002;347(25):204656. doi: 10.1056/NEJMra020398.

5. Ernst E. How Much of CAM is based on research evidence? Evid Based Complement Alternat Med. 2011;2011:676490.

6. Adelekun TA, Ekwere TR, Akinsola A. The pattern of local traditions, it contrasts with the knowledge brought by scientific research, in a way that the latter is seen with skepticism by the general population. It is also important to highlight that, mostly in developing countries, access to scientific material is restricted to few, which poses as a barrier between scientific knowledge and day-to-day applicability.

Considering the feasibility of the subject, the plants studied should correspond to $\mathrm{MH}$ that are actually being used by local populations. Nevertheless, should we analyze the $\mathrm{MH}$ which appeared most frequently in our electronic search, such as Tripterygium wilfordii, Hypericum perforatum L. and Glycyrrhiza glabra, they might not necessarily correlate with the ones which are mostly taken in Brazil. Even in databases more directed to Latin America publications, such as LILACS and SciELO, we had difficulties to find credible information about the most commonly used MH in Brazil. In most cases, the few studies that actually exist tend to focus only on small provinces or indigenous tribes ${ }^{57,58}$, which do not correspond to Brazilian general population.

Therefore, it is extremely important that governments act as a bridge between science and population, implementing scientific knowledge in a universal healthcare system. This is a means through which the current misconception of $\mathrm{MH}$ can be gradually demystified. General population, physicians and other healthcare professionals should stop looking at natural products as innocent or beneficial compounds; they may be considered, as we have shown throughout our review, even as lethal agents. Consequently, physicians should obtain a detailed dietary history of his or her patient, actively seeking for MH usage.

Finally, this review clearly shows the absence of clinical investigations regarding renal adverse effects of $\mathrm{MH}$, whose usage as a choice of treatment has been more and more employed nowadays.

acute toxic nephropathy in Ife, Nigeria. West Afr J Med. 1999;18(1):60-3.

7. Hilepo JN, Bellucci AG, Mossey RT. Acute renal failure caused by 'cat's claw' herbal remedy in a patient with systemic lupus erythematosus. Nephron. 1997;77(3):361. doi: 10.1159/000190304.

8. Izumotani T, Ishimura E, Tsumura K, Goto K, Nishizawa $\mathrm{Y}$, Morii H. An adult case of Fanconi syndrome due to a mixture of Chinese crude drugs. Nephron. 1993;65(1):137-40. doi: $10.1159 / 000187455$.

9. Sontia B, Mooney J, Gaudet L, Touyz RM. Pseudohyperaldosteronism, liquorice, and hypertension. J Clin Hypertens (Greenwich). 2008;10(2):153-7. doi: 10.1111/j.1751-7176.2008.07470.x.

10. Mueller BA, Scott MK, Sowinski KM, Prag KA. Noni juice (Morinda citrifolia): hidden potential for hyperkalemia? Am J Kidney Dis. 2000;35(2):310-2. doi: 10.1016/S02726386(00)70342-8. 
11. Segasothy M, Samad S. Illicit herbal preparation containing phenylbutazone causing analgesic nephropathy. Nephron. 1991;59(1):166-7. doi: 10.1159/000186543.

12. Vanherweghem JL, Depierreux M, Tielemans C, Abramowicz D, Dratwa M, Jadoul M, et al. Rapidly progressive interstitial renal fibrosis in young women: association with slimming regimen including Chinese herbs. Lancet. 1993;341(8842):387-91. doi: 10.1016/0140-6736(93)929842.

13. Powell T, Hsu FF, Turk J, Hruska K. Ma-huang strikes again: ephedrine nephrolithiasis. Am J Kidney Dis. 1998;32(1):1539. doi: 10.1053/ajkd.1998.v32.pm9669437.

14. Cosyns JP, Jadoul M, Squifflet JP, Van Cangh PJ, van Ypersele de Strihou C. Urothelial malignancy in nephropathy due to Chinese herbs. Lancet. 1994;344(8916):188. https://doi. org/10.1016/S0140-6736(94)92786-3.

15. Marcus DM, Grollman AP. Botanical medicines--the need for new regulations. N Engl J Med. 2002;347(25):2073-6. doi: 10.1056/NEJMsb022858.

16. Isnard Bagnis C, Deray G, Baumelou A, Le Quintrec M, Vanherweghem JL. Herbs and the kidney. Am J Kidney Dis. 2004;44(1):1-11. doi: 10.1053/j.ajkd.2004.02.009.

17. Gold $\mathrm{CH}$. Acute renal failure from herbal and patent remedies in Blacks. Clin Nephrol. 1980;14(3):128-34.

18. Dukes DC, Dukes HM, Gordon JA, Mynors JM, Weinberg RW, Davidson LA. Acute renal failure in Central Africa. The toxic effects of traditional African medicine. Cent Afr J Med. 1969;15(4):71-8

19. Otieno LS, McLigeyo SO, Luta M. Acute renal failure following the use of herbal remedies. East Afr Med J. 1991;68(12):993-8

20. Seedat YK. Acute renal failure in the black population of South Africa. Int J Artif Organs. 1993;16(12):801-2.

21. Omar HR, Komarova I, El-Ghonemi M, Fathy A, Rashad R, Abdelmalak HD, et al. Licorice abuse: time to send a warning message. Ther Adv Endocrinol Metab. 2012;3(4):125-38. doi: $10.1177 / 2042018812454322$

22. Stewart PM, Wallace AM, Valentino R, Burt D, Shackleton $\mathrm{CH}$, Edwards CR. Mineralocorticoid activity of liquorice: 11-beta-hydroxysteroid dehydrogenase deficiency comes of age. Lancet. 1987;2(8563):821-4. doi: 10.1016/S01406736(87)91014-2.

23. Diamond JR, Pallone TL. Acute interstitial nephritis following use of tung shueh pills. Am J Kidney Dis. 1994;24(2):219-21. doi: 10.1016/S0272-6386(12)80186-7.

24. Vanherweghem LJ. Misuse of herbal remedies: the case of an outbreak of terminal renal failure in Belgium (Chinese herbs nephropathy). J Altern Complement Med. 1998;4(1):9-13. doi: 10.1089/acm.1998.4.1-9.

25. Breidenbach T, Kliem V, Burg M, Radermacher J, Hoffmann MW, Klempnauer J. Profound drop of cyclosporin A whole blood trough levels caused by St. John's wort (Hypericum perforatum). Transplantation. 2000;69(10):2229-30. doi: 10.1097/00007890-200005270-00052.

26. World Health Organization - WHO. General guidelines for methodologies on research and evaluation of traditional medicine. Geneva; 2000. (WHO/EDM/ TRM/2000.1). Available from: http://apps.who.int/iris/ bitstream/10665/66783/1/WHO_EDM_TRM 2000.1.pdf.

27. Posadzki P, Watson LK, Ernst E. Adverse effects of herbal medicines: an overview of systematic reviews. Clin Med
(Lond). 2013;13(1):7-12. doi: 10.7861/clinmedicine.13-1-7

28. Nowack R. Review article: cytochrome P450 enzyme, and transport protein mediated herb-drug interactions in renal transplant patients: grapefruit juice, St John's Wort - and beyond! Nephrology (Carlton). 2008;13(4):337-47. doi: 10.1111/j.1440-1797.2008.00940.x.

29. Boubaker K, Ounissi M, Brahmi N, Goucha R, Hedri $\mathrm{H}$, Abdellah TB, et al. Acute renal failure by ingestion of Euphorbia paralias. Saudi J Kidney Dis Transpl. 2013;24(3):571-5. doi: 10.4103/1319-2442.111069

30. Kang KS, Heo ST. A case of life-threatening acute kidney injury with toxic encephalopathy caused by Dioscorea quinqueloba. Yonsei Med J. 2015;56(1):304-6. doi: 10.3349/ ymj.2015.56.1.304.

31. Qurashi HE, Qumqumji AA, Zacharia Y. Acute renal failure and intravascular hemolysis following henna ingestion. Saudi J Kidney Dis Transpl. 2013;24(3):553-6. doi: 10.4103/13192442.111065.

32. Wong JS, Ong TA, Chua HH, Tan C. Acute anuric renal failure following jering bean ingestion. Asian J Surg. 2007;30(1):801. doi: 10.1016/S1015-9584(09)60134-2.

33. Nowack R, Balle C, Birnkammer F, Koch W, Sessler R, Birck R. Impact of food and herbal medication on calcineurin inhibitor dose in renal transplant patients: a cross-sectional study. J Med Food. 2011;14(7-8):756-60. doi: 10.1089/ jmf.2010.0163.

34. Mueller BA, Scott MK, Sowinski KM, Prag KA. Noni juice (Morinda citrifolia): hidden potential for hyperkalemia? Am J Kidney Dis. 2000;35(2):310-2. doi: 10.1016/S02726386(00)70342-8.

35. Egashira K, Fukuda E, Onga T, Yogi Y, Matsuya F, Koyabu $\mathrm{N}$, et al. Pomelo-induced increase in the blood level of tacrolimus in a renal transplant patient. Transplantation. 2003;75(7):1057. doi: 10.1097/01.TP.0000058545.35041.BE.

36. Nowack R, Nowak B. Herbal teas interfere with cyclosporin levels in renal transplant patients. Nephrol Dial Transplant. 2005;20(11):2554-6. doi: 10.1093/ndt/gfi003.

37. Chou WC, Wu CC, Yang PC, Lee YT. Hypovolemic shock and mortality after ingestion of Tripterygium wilfordii hook F.: a case report. Int J Cardiol. 1995;49(2):173-7. doi: 10.1016/0167-5273(95)02282-2.

38. Edwards DJ, Fitzsimmons ME, Schuetz EG, Yasuda K, Ducharme MP, Warbasse LH, et al. 6', 7'-Dihydroxybergamottin in grapefruit juice and Seville orange juice: effects on cyclosporine disposition, enterocyte CYP3A4, and P-glycoprotein. Clin Pharmacol Ther. 1999;65(3):237-44. doi: 10.1016/S0009-9236(99)70102-5.

39. Talasaz AH, Abbasi MR, Abkhiz S, Dashti-Khavidaki S. Tribulus terrestris-induced severe nephrotoxicity in a young healthy male. Nephrol Dial Transplant. 2010;25(11):3792-3. doi: $10.1093 / \mathrm{ndt} / \mathrm{gfq} 457$.

40. Antonio J, Uelmen J, Rodriguez R, Earnest C. The effects of Tribulus terrestris on body composition and exercise performance in resistance-trained males. Int J Sport Nutr Exerc Metab. 2000;10(2):208-15. doi: 10.1123/ijsnem.10.2.208.

41. Al-Ali M, Wahbi S, Twaij H, Al-Badr A. Tribulus terrestris: preliminary study of its diuretic and contractile effects and comparison with Zea mays. J Ethnopharmacol. 2003;85(23):257-60. doi: 10.1016/S0378-8741(03)00014-X.

42. Joshi VS, Parekh BB, Joshi MJ, Vaidya AD. Inhibition of the growth of urinary calcium hydrogen phosphate dihydrate 
Figueredo MS, et al. Adverse effects of medicinal herbs on the human kidney.

crystals with aqueous extracts of Tribulus terrestris and Bergenia ligulata. Urol Res. 2005;33(2):80-6. doi: 10.1007/ s00240-004-0450-6.

43. Zhang XY, Tsuchiya N, Dohi M, Yamamoto K, Ishihara K, Okudaira $\mathrm{H}$, et al. Prolonged survival of MRL-lpr/lpr mice treated with Tripterygium Wilfordii Hook-F. Clin Immunol Immunopathol. 1992;62(1 Pt 1):66-71. doi: 10.1016/00901229(92)90023-H.

44. Kao NL, Richmond GW, Moy JN. Resolution of severe lupus nephritis associated with Tripterygium wilfordii hook F ingestion. Arthritis Rheum. 1993;36(12):1751-2. doi: 10.1002/art.1780361217.

45. Ram R, Swarnalatha G, Prasad N, Dakshinamurty KV. Paraphenylene diamine ingestion: an uncommon cause of acute renal failure. J Postgrad Med. 2007;53(3):181-2. doi: 10.4103/0022-3859.33860.

46. van Gurp G, Meterissian GB, Haiek LN, McCusker J, Bellavance F. St John's wort or sertraline? Randomized controlled trial in primary care. Can Fam Physician. 2002;48:905-12. Available from: http://www.cfp.ca/content/ cfp/48/5/905.full.pdf.

47. Wheatley D. LI 160, an extract of St. John's wort, versus amitriptyline in mildly to moderately depressed outpatients-a controlled 6-week clinical trial. Pharmacopsychiatry. 1997;30(Suppl 2):77-80. doi: 10.1055/s-2007-979523.

48. Kasper S, Anghelescu IG, Szegedi A, Dienel A, Kieser M. Superior efficacy of St John's wort extract WS 5570 compared to placebo in patients with major depression: a randomized, double-blind, placebo-controlled, multi-center trial [ISRCTN77277298]. BMC Med. 2006;4:14. doi: 10.1186/1741-7015-4-14.

49. Foster BC, Vandenhoek S, Hana J, Krantis A, Akhtar MH, Bryan $\mathrm{M}$, et al. In vitro inhibition of human cytochrome P450-mediated metabolism of marker substrates by natural products. Phytomedicine. 2003;10(4):334-42. doi: 10.1078/094471103322004839.

50. Breidenbach T, Kliem V, Burg M, Radermacher J, Hoffmann
MW, Klempnauer J. Profound drop of cyclosporin A whole blood trough levels caused by St. John's wort (Hypericum perforatum). Transplantation. 2000;69(10):2229-30. doi: 10.1097/00007890-200005270-00052.

51. Mai I, Kruger H, Budde K, Johne A, Brockmoller J, Neumayer $\mathrm{HH}$, et al. Hazardous pharmacokinetic interaction of Saint John's wort (Hypericum perforatum) with the immunosuppressant cyclosporin. Int J Clin Pharmacol Ther. 2000;38(10):500-2. doi: 10.5414/CPP38500.

52. Tassaneeyakul W, Guo LQ, Fukuda K, Ohta T, Yamazoe Y. Inhibition selectivity of grapefruit juice components on human cytochromes P450. Arch Biochem Biophys. 2000;378(2):3566. doi: 10.1006/abbi.2000.1835.

53. Egashira K, Ohtani H, Itoh S, Koyabu N, Tsujimoto M, Murakami $\mathrm{H}$, et al. Inhibitory effects of pomelo on the metabolism of tacrolimus and the activities of CYP3A4 and P-glycoprotein. Drug Metab Dispos. 2004;32(8):828-33. doi: 10.1124/dmd.32.8.828.

54. Lown KS, Mayo RR, Leichtman AB, Hsiao HL, Turgeon DK, Schmiedlin-Ren P, et al. Role of intestinal P-glycoprotein $(\mathrm{mdr} 1)$ in interpatient variation in the oral bioavailability of cyclosporine. Clin Pharmacol Ther. 1997;62(3):248-60. doi: 10.1016/S0009-9236(97)90027-8.

55. Lin HY, Rocher LL, McQuillan MA, Schmaltz S, Palella TD, Fox IH. Cyclosporine-induced hyperuricemia and gout. N Engl J Med. 1989;321(5):287-92. doi: 10.1056/ NEJM198908033210504.

56. Naesens M, Kuypers DR, Sarwal M. Calcineurin inhibitor nephrotoxicity. Clin J Am Soc Nephrol. 2009;4(2):481-508. doi: 10.2215/CJN.04800908

57. Amorozo M. Use and diversity of medicinal plants in Santo Antonio do Leverger, MT, Brazil. Acta Bot. Bras. 2002; 16(2); 189-203. doi: 10.1590/S0102-33062002000200006.

58. Agra M, Silva K, Basílio D, Freitas P, Barbosa-Filho J. Survey of medicinal plants used in the region Northeast of Brazil. Braz J Pharmacol. 2008;18 (3);472-508. doi: 10.1590/ S0102-695X2008000300023. 